\title{
Variation in food sources of the macrobenthos along a land-sea transect: a stable isotope study
}

\author{
H. Yokoyama*, Y. Ishihi
}

National Research Institute of Aquaculture, Fisheries Research Agency, Minami-Ise, Mie 516-0193, Japan

\begin{abstract}
To evaluate the relative importance for the macrobenthos of possible food sources, including riverine particulate organic matter, reeds, benthic microalgae, seaweeds, coastal phytoplankton and aquaculture-derived matter, over 194 macrofaunal species were collected from 9 intertidal and subtidal stations along the axis of Gokasho Bay, Japan, and their isotopic compositions analyzed. The $\delta^{13} \mathrm{C}$ values for terrestrial organic matter were very different from those of the consumers $(>5 \%)$, suggesting a negligible trophic role for this source. Differences in $\delta^{15} \mathrm{~N}$ between seaweeds and primary consumers were small, suggesting a minor contribution of seaweeds. The $\delta^{13} \mathrm{C}$ values of the majority of consumers fell between coastal phytoplankton and benthic microalgae, allowing the calculation of the relative contribution of these microalgae to the diets of consumers. The estimated contribution ratios and the between-site comparison of the $\delta^{13} \mathrm{C}$ value for the same species along the bay axis suggest a shift of the main food source from benthic microalgae on the mudflat to coastal phytoplankton at the subtidal seaward stations. Several consumers collected from the fish-farm area had enriched $\delta^{15} \mathrm{~N}$ and depleted $\delta^{13} \mathrm{C}$ values relative to samples of the same species that occurred outside of the farm area. The $\delta^{13} \mathrm{C}$ values of the consumers at the fish farm were significantly more depleted than those at the other stations. These findings suggest that the consumers inhabiting the farming area incorporate ${ }^{15} \mathrm{~N}$-enriched fish meal and ${ }^{13} \mathrm{C}$-reduced cereals that are major constituents of fish feed.
\end{abstract}

KEY WORDS: Stable isotopes - Macrobenthos - Benthic microalgae $\cdot$ Phytoplankton · Tidal flat · Fish farm Resale or republication not permitted without written consent of the publisher

\section{INTRODUCTION}

Nearshore coastal areas constitute extremely productive environments, due largely to the high concentrations and varied potential sources of organic matter and nutrients, which are derived from both freshwater and marine sources. Such areas also receive anthropogenic inputs, often resulting in environmental deterioration. Macrobenthos is an important component of coastal ecosystems that utilizes this high productivity and has the potential to ameliorate environmental deterioration either directly or indirectly. It is necessary to obtain information on food sources of the macrobenthos in order to understand the role of the macrobenthos in coastal ecosystems.

Stable isotope analyses have commonly been used to identify food sources of aquatic animals by provid- ing signatures based on actual assimilation over a period corresponding to the turnover time of the tissues analyzed. Stable carbon isotope ratios $\left(\delta^{13} \mathrm{C}\right)$ have been used to elucidate the sources of nutrition of consumers, based on the close relationship between the $\delta^{13} \mathrm{C}$ of the food items and that of the consumer (DeNiro \& Epstein 1978), while stable nitrogen ratios $\left(\delta^{15} \mathrm{~N}\right)$ have been applied to investigations of the trophic structure, because of the large and consistent ${ }^{15} \mathrm{~N}$ enrichment with increasing trophic level (DeNiro \& Epstein 1981, Minagawa \& Wada 1984). There is however variability in the diet-tissue isotopic fractionation for both carbon and nitrogen, and it has been suggested that it is important to obtain speciesspecific fractionation for the estimation of the food source and trophic position of consumers (e.g. McCutchan et al. 2003). 
The stable isotope approach is based on the assumption that the number of potential food sources is limited and each exhibits a distinct isotopic composition. The coupling of $\delta^{13} \mathrm{C}$ and $\delta^{15} \mathrm{~N}$ values results in a bidimensional separation of 2 or 3 potential food sources for consumers. Phillips \& Gregg (2003) proposed an empirical approach to explore the range of solutions possible, given known signatures in situations where there are $>3$ food sources. Lee (2005), however, suggested that this approach still fails to directly relate consumers to their food source and that mixing models are not always effective in elucidating the actual trophic pattern.

Gokasho Bay, which is located on the Pacific coast of central Japan, is characterized by various habitats such as tidal flats, Sargassum beds, sandy and rocky shores and sand and mud sea floors, which receive natural and aquaculture-derived organic matter. In the present study, we sampled intertidal and subtidal macrobenthos along a land-sea transect, along which there is a potential shift in the primary carbon source, and assessed the relative importance of potential food sources including terrestrial plants, seaweeds, benthic microalgae, coastal phytoplankton and aquaculturederived organic matter to the diets of benthic consumers. Recently, Yokoyama et al. (2005a) quantified the diet-tissue isotopic fractionation for 2 bivalves and 2 ghost shrimps. In the present study, these fractionation values were used for assessment of the food sources.

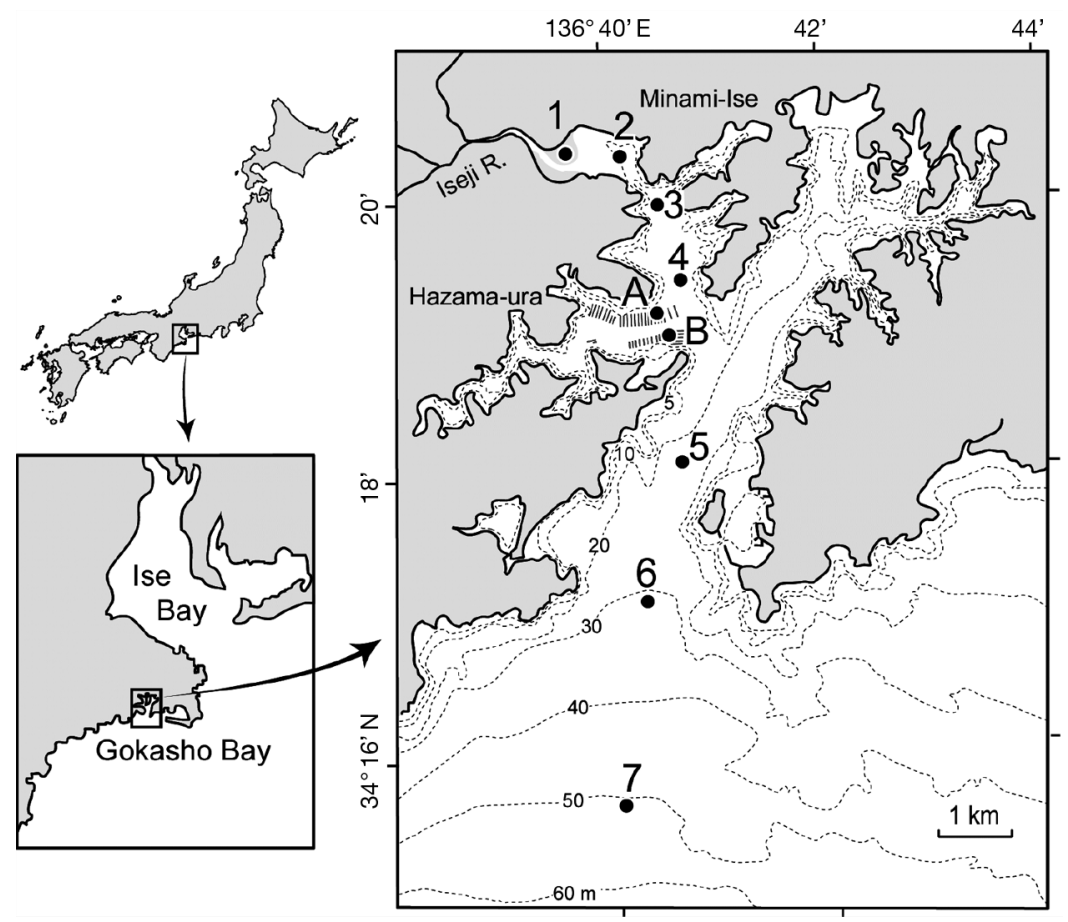

Fig. 1. Sampling stations (Stns 1 to 7, A, B) with depth contours (broken lines). Fish cage rows are shown as hatching around Stns A and B

\section{MATERIALS AND METHODS}

Study area. Gokasho Bay has an area of $22.2 \mathrm{~km}^{2}$ and a mean depth of $12.7 \mathrm{~m}$ (Fig. 1). The shoreline of the bay is constituted mainly of rocky reefs, and partly of sandy beaches. Freshwater flows into the bay mainly from the Iseji River which drains $39 \mathrm{~km}^{2}$ of forested land covered by evergreen broad-leaved trees $\left(\mathrm{C}_{3}\right.$ plants $)$ that are almost free of anthropogenic influence. The reed Phragmites australis occurs sparsely on the river shores on the lower sections of the Iseji River. The flow rate of this river is relatively low, with an average of $1.1 \mathrm{~m}^{3} \mathrm{~s}^{-1}$, but occasionally reaches $8.5 \mathrm{~m}^{3}$ $\mathrm{s}^{-1}$ during the rainy season from June to July and during the typhoon season from August to September (Iwasaki et al. 1997). In these seasons, the surface layer $(<5 \mathrm{~m})$ in Gokasho Bay is often covered with low salinity water (<30) (Abo et al. 2000), and contains terrestrial sediments and organic matter $(\mathrm{H}$. Yokoyama unpubl. data). Even in the rainy and typhoon seasons, the bottom water deeper than $10 \mathrm{~m}$ remains at relatively high salinity levels ( $>32$ ), due to vertical stratification and the large water exchange between the inside and the outside of the bay, driven by the internal tide and periodic coastal upwellings (Abo 2000). Mudflats appear at the mouth of the Iseji River, extending over an area of 25 ha at the lowest ebb tide. The mudflats are bare and vascular saltmarsh plants are absent, but fragments of reed that have been carried by the river are occasionally found there. Seaweeds, primarily Sargassum species (S. fusiformis, S. hemiphyllum, S. horneri, S. patens, S. piluliferum and $S$. thunbergii) are densely distributed in the central part of Gokasho Bay from mid winter through early summer (Yokoyama \& Ishihi 2003).

In Gokasho Bay, fish farming has developed during the last 4 decades. In 2002, $1490 \mathrm{t}$ of fish (red sea bream Pagrus major and yellowtail Seriola quinqueradiata) were produced by supplying moist and dry feed pellets (Yokoyama et al. 2006). Most fish cages (84\%) are distributed in Hazama-ura cove. In this area, azoic conditions are found from June through November, due to deoxygenation; after December, macrofauna recovers through successive recruitments of diminutive species such as the polychaetes Capitella sp., Pseudopolydora paucibranchiata and Schistomeringos sp., and density, biomass and species richness peak from March to April (Yokoyama 2002). 
Sample collection. Macrobenthic animals were collected from 9 stations (Fig. 1) from March 28 to June 5, 2002. The average precipitation during this period at Minami-Ise $\left(34^{\circ} 20.7^{\prime} \mathrm{N}, 136^{\circ} 40.9^{\prime} \mathrm{E}\right)$ was $6.4 \mathrm{~mm} \mathrm{~d}^{-1}$, which is approximately the same level as the yearly mean value in this locality $\left(5.6 \mathrm{~mm} \mathrm{~d}^{-1}\right.$ in 2002) (Japan Meteorological Agency, available at www.data.jma. go.jp/obd/stats/etrn/index.php). Stn 1 was located on an intertidal mudflat at the mouth of Iseji River. Stns 2 to 7 were on subtidal mud (Stns 2 to 4 ) and sand (Stns 5 to 7 ) bottom along a transect fixed between the innermost part and the outside of Gokasho Bay. The water depths at Stns 2 to 7 were $4 \mathrm{~m}, 16 \mathrm{~m}, 19 \mathrm{~m}, 23 \mathrm{~m}, 31 \mathrm{~m}$ and $51 \mathrm{~m}$, respectively. Stns A and B were located on mud bottom (19 $\mathrm{m}$ water depth) between fish-cage rows in the northern and southern part of the fish farm in Hazama-ura cove. The distance of Stns A and B from the edge of the fish cage was approximately $20 \mathrm{~m}$, where aquaculture-derived organic matter was densely deposited (Yokoyama et al. 2006).

At Stn 1, benthic animals were collected by hand or a handheld net, or by sieving sediments with a $1 \mathrm{~mm}$ mesh sieve. Fragments of the reed Phragmites australis which had been carried by the river and drifted onto the mudflat were also collected. At the subtidal stations, macrobenthos was collected with an Ekman grab and a $1 \mathrm{~mm}$ mesh sieve. For the analysis of sedimentary organic matter (SOM), surface sediments to a depth of $1 \mathrm{~cm}$ were collected with an acrylic tube attached to the inside wall of the Ekman grab.

Sample processing for isotopic analysis. For the mollusks, shells were removed and the total soft tissues were used as samples. For the decapod crustaceans, muscle tissues were extracted from abdominal segments or pereiopods. The other small crustaceans and animals of other taxonomic groups were analyzed whole, except for small pieces which were preserved for identifying species. Intestine contents were removed when we found them. The animal tissues were soaked in $1.2 \mathrm{~N} \mathrm{HCl}$ for a few minutes to remove traces of carbonates, and when no $\mathrm{CO}_{2}$ bubbles were no longer observed, rinsed with distilled water briefly, dried at $60^{\circ} \mathrm{C}$ and ground to a fine powder. Such $\mathrm{HCl}$ treatment has no significant effect on the $\delta^{13} \mathrm{C}$ and $\delta^{15} \mathrm{~N}$ of animal tissues (Yokoyama \& Ishihi 2006). Animal samples for isotopic analysis were prepared for individual specimens. Numbers of samples of the same species per station ranged from 1 to 8 .

The sediment samples were soaked in $1.2 \mathrm{~N} \mathrm{HCl}$ overnight to remove carbonates, filtered on a Nuclepore polycarbonate track-etch membrane filter (pore size $=0.2 \mu \mathrm{m})$, rinsed with distilled water, dried at $60^{\circ} \mathrm{C}$ and ground to a fine powder.

The ${ }^{15} \mathrm{~N}$ and ${ }^{13} \mathrm{C}$ compositions of the samples were determined using a mass spectrometer (MAT 252,
Finnigan MAT) coupled online via a Finnigan ConFlo II interface with an elemental analyzer (EA 1110, ThermoQuest). Results are expressed in the standard $\delta$ unit notation as $\delta X=\left[\left(R_{\text {samples }} / R_{\text {reference }}\right)-1\right] \times 10^{3}$, where $X$ is ${ }^{13} \mathrm{C}$ or ${ }^{15} \mathrm{~N}$ and $R={ }^{13} \mathrm{C} /{ }^{12} \mathrm{C}$ for carbon, and ${ }^{15} \mathrm{~N} /{ }^{14} \mathrm{~N}$ for nitrogen. These values are reported relative to the Vienna Pee Dee Belemnite standard (PDB) for carbon and to air $\mathrm{N}_{2}$ for nitrogen.

Specifying the isotopic compositions for potential food sources. Major potential food sources for consumers in the study area include particulate organic matter in river water (riverine POM), benthic microalgae on the tidal flat, seaweeds, particulate organic matter in seawater (marine POM) and aquaculturederived organic matter including waste feed and fecal matter that had been excreted from cultured fish. Yokoyama \& Ishihi (2003) indicated that riverine POM and marine POM in the study area originate largely from terrestrial organic matter $\left(\mathrm{C}_{3}\right.$ plants $)$ and coastal phytoplankton (PP), respectively, and they (op. cit.) document year-round $\delta^{13} \mathrm{C}$ and $\delta^{15} \mathrm{~N}$ values of these POMs and benthic microalgae on the tidal flat. Assuming that the $\delta^{13} \mathrm{C}$ and $\delta^{15} \mathrm{~N}$ values of benthic animals reflect the isotopic compositions of the diet for the 2 to 3 mo prior to collection, the mean $( \pm \mathrm{SD}) \delta^{13} \mathrm{C}$ and $\delta^{15} \mathrm{~N}$ values of these primary producers during the period from February to May $(\mathrm{n}=4)$ were $-25.9 \pm 1.1$ and $0.2 \pm$ $1.1 \%$ for riverine POM, $-20.5 \pm 0.4$ and $5.9 \pm 1.4 \%$ for marine POM, and $-12.5 \pm 2.5$ and $5.1 \pm 1.0 \%$ o for benthic microalgae, respectively. Mean $( \pm \mathrm{SD}) \delta^{13} \mathrm{C}$ and $\delta^{15} \mathrm{~N}$ for the 6 Sargassum species found were $-15.0 \pm 2.9(n=129)$ and $8.1 \pm 1.0 \%$ o $(n=129)$ (authors' unpubl. data), respectively, and are adopted here as representative values of seaweeds. Yokoyama et al. (2006) estimated the $\delta^{13} \mathrm{C}$ and $\delta^{15} \mathrm{~N}$ of organic matter that originates from fish farming and deposits on the seabed in Gokasho Bay as -20.2 and $9.7 \%$ for waste feed and -24.3 and $6.3 \%$ for fecal matter, respectively. Fig. 2 summarizes the isotopic compositions of these potential food sources.

Mixing model. The contribution ratio (CR) of the 2 food sources to the estimated diet of the consumers was calculated based on the dual isotope model (Yokoyama et al. 2002). CR (\%) of the end member $\left(E_{1}\right)$ to the diet of a consumer (C) is determined by $\mathrm{CR}=$ $100 d_{2} /\left(d_{1}+d_{2}\right)$, where $d_{1}$ and $d_{2}$ are the distances from a hypothesized feed mixture $(F)$ of the consumer to $E_{1}$ and another end member $E_{2}$, respectively (Fig. 3). The slope $(S)$ of the trophic-enrichment line CF is defined as $S={ }^{15} \mathrm{~N}$ fractionation $/{ }^{13} \mathrm{C}$ fractionation. CR is calculated by $\mathrm{CR}=100\left(S \cdot C_{\mathrm{C}}-S \cdot E_{2 \mathrm{C}}-C_{\mathrm{N}}+E_{2 \mathrm{~N}}\right) /\left(S \cdot E_{1 \mathrm{C}}-\right.$ $\left.S \cdot E_{2 \mathrm{C}}-E_{1 \mathrm{~N}}+E_{2 \mathrm{~N}}\right)$, where $C_{\mathrm{C}}$ and $C_{\mathrm{N}}$ are the $\delta^{13} \mathrm{C}$ and $\delta^{15} \mathrm{~N}$ values of the consumer, $E_{1 \mathrm{C}}$ and $E_{1 \mathrm{~N}}$ are the $\delta^{13} \mathrm{C}$ and $\delta^{15} \mathrm{~N}$ values of the target end member, and $E_{2 \mathrm{C}}$ and $E_{2 \mathrm{~N}}$ are the $\delta^{13} \mathrm{C}$ and $\delta^{15} \mathrm{~N}$ values of another end mem- 


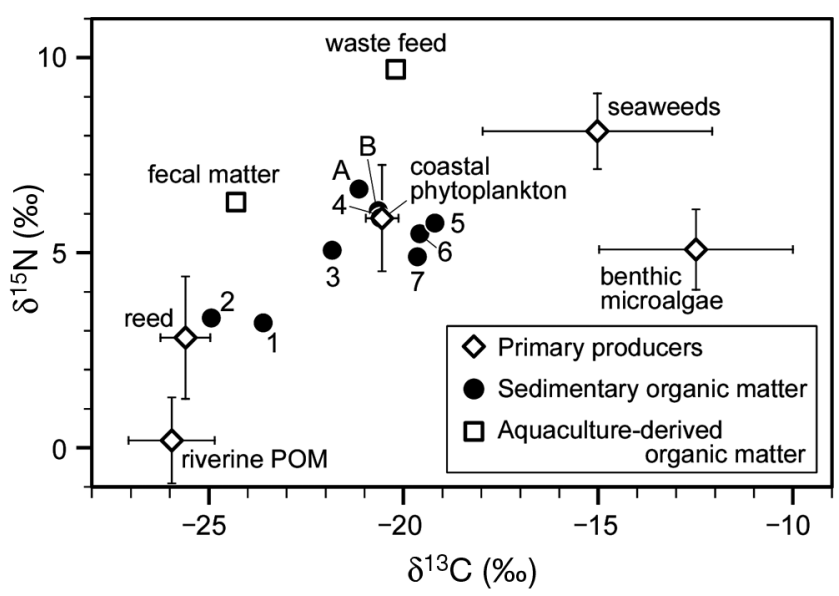

Fig. 2. Dual isotope plot of $\delta^{13} \mathrm{C}$ vs $\delta^{15} \mathrm{~N}$ for potential food sources for consumers. Numerals ' 1 to 7 ' and letters ' $A, B$ ' indicate sampling stations (see Fig. 1). Error bars are SD for the primary producers. Data on riverine particulate organic matter (POM), coastal phytoplankton collected as marine POM, seaweeds, benthic microalgae, waste feed and fecal matter of cultured fish are based on Yokoyama \& Ishihi (2003), Yokoyama et al. (2006) and our unpublished data (see text)

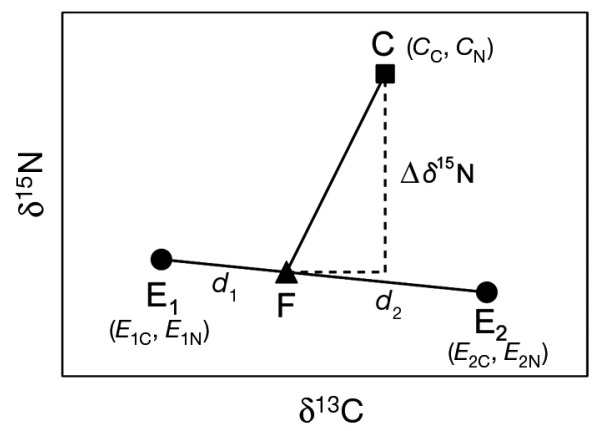

Fig. 3. Dual isotope model. Schematic diagram for calculating the contribution ratio of 2 end-members in the diet of an animal. See 'Materials and methods: Mixing model' for an explanation of the abbreviations

ber, respectively. In the present calculation, slopes used for the trophic enrichment lines were 4.375 for total soft tissues of bivalves, 2.0 for muscle tissues of decapods and 3.4 for animals of other taxonomic groups. These values were based on average values of diet-tissue ${ }^{13} \mathrm{C}$ and ${ }^{15} \mathrm{~N}$ fractionation for the 2 bivalves Mactra veneriformis and Ruditapes philippinarum $\left({ }^{13} \mathrm{C}\right.$ fractionation $=0.8 \%,{ }^{15} \mathrm{~N}$ fractionation $=3.5 \%$ ) and for the muscle of the 2 mud shrimps Nihonotrypaea japonica and $N$. harmandi $(2.0,4.0 \%)$, which had been determined in a laboratory feeding experiment (Yokoyama et al. 2005a) and based on the traditional fractionation values $(1.0,3.4 \%$ : DeNiro \& Epstein 1978, 1981, Minagawa \& Wada 1984), respectively.

The actual degree of fractionation varies considerably, depending on the species and tissue type ana- lyzed. Recently, McCutchan et al. (2003) showed a mean $( \pm \mathrm{SD}){ }^{15} \mathrm{~N}$ fractionation value of $2.3 \pm 1.5 \%$ for various kinds of consumers, excluding fluid-feeders (e.g. aphids or internal parasites). Assuming that this 'mean - $1 \mathrm{SD}^{\prime}$, i.e. $0.8 \%$ is the most depleted possible value of the ${ }^{15} \mathrm{~N}$ trophic fractionation in the present study, we adopted the calculated CR values when the difference between the $\delta^{15} \mathrm{~N}$ of a consumer and its hypothesized feed mixture $\left(\Delta \delta^{15} \mathrm{~N}\right)$ was calculated to be $>0.8 \%$. The $\Delta \delta^{15} \mathrm{~N}$ is given by $\left\{S \cdot C_{\mathrm{C}}\left(E_{1 \mathrm{~N}}-E_{2 \mathrm{~N}}\right)+\right.$ $\left.S \cdot C_{\mathrm{N}}\left(E_{2 \mathrm{C}}-E_{1 \mathrm{C}}\right)+S\left(E_{2 \mathrm{~N}} \cdot E_{1 \mathrm{C}}-E_{1 \mathrm{~N}} \cdot E_{2 \mathrm{C}}\right)\right\} /\left\{S\left(E_{2 \mathrm{C}}-\right.\right.$ $\left.\left.E_{1 \mathrm{C}}\right)-E_{2 \mathrm{~N}}+E_{1 \mathrm{~N}}\right\}$.

Statistical analysis. As variances were heterogeneous, a nonparametric one-way analysis of variance (Kruskal-Wallis test) was used to evaluate differences in the $\delta^{13} \mathrm{C}$ and $\delta^{15} \mathrm{~N}$ of consumers between stations. Where appropriate, a nonparametric post hoc multiple comparison test (Steel-Dwass test) was performed to evaluate pairwise differences between stations. For $\delta^{13} \mathrm{C}$ and $\delta^{15} \mathrm{~N}$ values of single consumer species appearing at 2 stations along the transect, or inside and outside of the fish farm, differences between stations were tested by paired $t$-tests.

Analysis of macrofauna. Specimens used for the isotopic analysis were identified to the lowest possible taxonomic level. The degree of affinity of the species composition between 2 stations was calculated based on the presence/absence data of species collected at each station using the Nomura-Simpson's coefficient (Nomura 1940, Simpson 1960). The Nomura-Simpson's coefficient is expressed as ' $c / b,(b<a)$ ', where $c$ is the number of species that occur at both stations, and $a$ and $b$ are the numbers of species collected from each station.

\section{RESULTS}

\section{Isotopic compositions of SOM and reeds}

Sedimentary organic matter (SOM) at Stns 1 and 2 had the most depleted $\delta^{13} \mathrm{C}(-24.9$ to $-23.6 \%)$ and $\delta^{15} \mathrm{~N}(3.2$ to $3.3 \%$ ) values (Fig. 2). The SOM values progressively increased toward the seaward station. Among Stns 1 to 7 , the most enriched $\delta^{13} \mathrm{C}(-19.2 \%)$ was found at Stn 5 , while the $\delta^{15} \mathrm{~N}$ was most enriched at Stn 4 (5.9\%). There was a decreasing trend in $\delta^{15} \mathrm{~N}$ of SOM from Stn 4 toward the most offshore station (Stn 7), where $4.9 \%$ was found. At the fish-farm stations (Stns A, B), the $\delta^{13} \mathrm{C}$ values $\left(-21.1\right.$ to $-20.6 \%$ ) were more depleted and the $\delta^{15} \mathrm{~N}$ values (6.1 to $6.6 \%$ ) were more enriched than those at the seaward stations (Stns 5 to 7 ).

The mean $( \pm \mathrm{SD}) \delta^{13} \mathrm{C}$ and $\delta^{15} \mathrm{~N}( \pm \mathrm{SD})$ of the reed Phragmites australis was $-25.6 \pm 0.6 \%$ o $(\mathrm{n}=3)$ and $2.8 \pm$ $1.6 \%$ o $(\mathrm{n}=3)$, respectively (Fig. 2 ). 


\section{Macrofauna}

All species collected are listed in Table 1. The dendrogram of the sampling stations based on the species composition shows that the macrofauna in the study area was classified into 4 groups, a group on the mudflat (Stn 1), a group in the inner bay area (Stns 2 to 4), a group in the seaward area (Stns 5 to 7) and a group in the fish-farm area (Stns A, B) (Fig. 4). The intertidal fauna on the mudflat was characterized by animals belonging to a variety of taxa (e.g. Gastropoda, Bivalvia, Polychaeta, Decapoda, and Osteichthyes). The macrofauna of the second group (Stns 2 to 4) was characterized by the high composition ratio of polychaete species (i.e. 27 species of 48 collected) and the occurrence of animals that are common to eutrophicated mud bottom in semi-enclosed bays in Japan, such as the bivalves Macoma incongrua and Theora lubrica, and the polychaetes Paraprionospio patiens and Scoletoma longifolia (Horikoshi 1990). The macrofauna of the third group was characterized by high species richness (a total of 96 species collected), a relatively high composition ratio of amphipods (19\%) and the occurrence of the lancelet Branchiostoma belcheri-a faunal composition characteristic of coastal sand bottoms with moderate tidal currents (Horikoshi 1990). The macrofauna in the fish-farm area was characterized by the occurrence of the polychaetes Capitella sp. and Schistomeringos sp. and Nebalia japonensis (a member of the Phyllocarida), taxa that are dominant in Japanese mariculture fish farms (Tsutsumi 1995, Sasaki \& Oshino 2004).

\section{Isotopic compositions of consumers}

Isotopic compositions of consumers and their potential food sources are shown in Fig. 5, and frequency distributions of $\delta^{13} \mathrm{C}$ and $\delta^{15} \mathrm{~N}$ values of the consumers at each station are shown in Fig. 6 . There were significant differences in the $\delta^{13} \mathrm{C}$ and $\delta^{15} \mathrm{~N}$ of the consumers among the stations (Kruskal-Wallis test, both $\mathrm{p}<0.001$ ).

Table 1. Benthic fauna collected at 9 stations along a land-sea transect in Gokasho Bay, Japan

\begin{tabular}{|c|c|c|c|c|c|}
\hline No. & Taxon & No. & Taxon & No. & Taxon \\
\hline \multicolumn{2}{|c|}{ Anthozoa } & 27 & Limatula vladivostokensis & 59 & Prionospio depauperata \\
\hline 1 & Unidentified Cerianthidae & 28 & Crassostrea gigas & 60 & Prionospio kurusadensis \\
\hline 2 & Unidentified Actiniaria & 29 & Raetellops pulchellus & 61 & Prionospio paradisea \\
\hline \multicolumn{2}{|c|}{ Platyhelminthes } & 30 & Exotica tokubeii & 62 & Prionospio pulchra \\
\hline 3 & Unidentified Polycladida & 31 & Moerella rutila & 63 & Rhynchospio glutaea \\
\hline \multicolumn{2}{|c|}{ Nemertinea } & 32 & Macoma tokyoensis & 64 & Pseudopolydora paucibranchiata \\
\hline 4 & Unidentified Palaeonemertea & 33 & Macoma incongrua & 65 & Pseudopolydora sp. \\
\hline 5 & Unidentified Lineidae & 34 & Theora lubrica & 66 & Scolelepis geniculata \\
\hline 6 & Unidentified Heteronemertea & 35 & Peregrinamor ohshimai & 67 & Spiophanes bombyx \\
\hline 7 & Unidentified Hoplonemertea & 36 & Fulvia bullata & 68 & Magelona sp. \\
\hline \multicolumn{2}{|c|}{ Tentaculata } & 37 & Anomalocardia squamosa & 69 & Poecilochaetus sp. \\
\hline 8 & Unidentified Phoronida & 38 & Pitar noguchii & 70 & Spiochaetopterus koreana \\
\hline \multicolumn{2}{|c|}{ Caudofoveata } & 39 & Pitar sulfureum & 71 & Unidentified Chaetopteridae \\
\hline 9 & Unidentified Caudofoveata & 40 & Ruditapes philippinarum & 72 & Aphelochaeta sp. \\
\hline \multicolumn{2}{|c|}{ Gastropoda } & 41 & Paphia undulata & 73 & Cirriformia sp. \\
\hline 10 & Monodonta labio confusa & 42 & Cyclina sinensis & 74 & Chaetozone sp. A \\
\hline 11 & Conotalopia ornata & 43 & Laternula anatina & 75 & Chaetozone sp. B \\
\hline 12 & Turbo coronatus coreensis & 44 & Laternula marilina & 76 & Chone sp. \\
\hline 13 & Batillaria multiformis & 45 & Plectodon ligulus & 77 & Hydroides elegans \\
\hline 14 & Batillaria cumingii & \multicolumn{2}{|c|}{ Sipuncula } & 78 & Capitella sp. \\
\hline 15 & Cerithidea djadjariensis & 46 & Apionsoma sp. & 79 & Heteromastus sp. \\
\hline 16 & Littoria brevicula & 47 & Phascolion sp. & 80 & Mediomastus sp. \\
\hline 17 & Unidentified Naticidae & 48 & Unidentified Sipuncula & 81 & Notomastus sp. A \\
\hline 18 & Natica buriasensis & \multicolumn{2}{|c|}{ Polychaeta } & 82 & Notomastus sp. B \\
\hline 19 & Reticunassa festiva & 49 & Phylo sp. & 83 & Unidentified Maldanidae \\
\hline 20 & Eocylichna braunsi & 50 & Scoloplos (Leodamas) sp. & 84 & Praxillella pacifica \\
\hline 21 & Unidentified Goniodorididae & 51 & Scoloplos (Scoloplos) sp. & 85 & Armandia sp. \\
\hline \multicolumn{2}{|c|}{ Scaphopoda } & 52 & Aricidea cerrutii pacifica & 86 & Anaitides sp. A \\
\hline 22 & Pulsellum hige & 53 & Aricidea simplex & 87 & Anaitides sp. B \\
\hline \multicolumn{2}{|c|}{ Bivalvia } & 54 & Aricidea sp. & 88 & Eulalia sp. \\
\hline 23 & Petrasma pusilla & 55 & Paradoneis nipponica & 89 & Harmothoe spinifera \\
\hline 24 & Oblimopa multistriata & 56 & Cossura duplex & 90 & Sigalion sp. \\
\hline 25 & Glycymeris imperialia & 57 & Aonides oxycephala & 91 & Sthenelais sp. \\
\hline 26 & Musculista senhousia & 58 & Paraprionospio patiens & 92 & Sthenolepis sp. \\
\hline
\end{tabular}

(Table continued on next next page) 
Table 1 (continued)

\begin{tabular}{|c|c|c|c|c|c|}
\hline \multicolumn{2}{|c|}{ No. $\quad$ Taxon } & No. & Taxon & \multicolumn{2}{|c|}{ No. Taxon } \\
\hline \multicolumn{2}{|c|}{ Polychaeta (cont.) } & \multicolumn{2}{|c|}{ Amphipoda } & 161 & Palaemon macrodactylus \\
\hline 93 & Gyptis sp. & 127 & Byblis japonicus & 162 & Athanas japonicus \\
\hline 94 & Ophiodromus sp. & 128 & Ampelisca brevicornis & 163 & Alpheus brevicristatus \\
\hline 95 & Sigambra phuketensis & 129 & Ampelisca miharaensis & 164 & Alpheus distinguendus \\
\hline 96 & Neanthes caudata & 130 & Ampelisca naikaiensis & 165 & Alpheus lobidens lobidens \\
\hline 97 & Glycera alba & 131 & Aoroides sp. & 166 & Ogyrides striaticauda \\
\hline 98 & Glycera macintoshi & 132 & Urothoe sp. & 167 & Processa sulcata \\
\hline 99 & Glycera nicobarica & 133 & Stenothoe sp. & 168 & Laomedia astacina \\
\hline 100 & Glycera sp. & 134 & Harpiniopsis sp. & 169 & Upogebia major \\
\hline 101 & Glycinde sp. & 135 & Synchelidium sp. & 170 & Paguristes ortmanni \\
\hline 102 & Aglaophamus sinensis & 136 & Argissa hamatipes & 171 & Pagurus dubius \\
\hline \multirow[t]{2}{*}{103} & Micronephtys sphaerocirrata & 137 & Melita sp. & 172 & Nursia japonica \\
\hline & orientalis & 138 & Elasmopus japonicus & 173 & Philyra pisum \\
\hline 104 & Nephtys oligobranchia & 139 & Melphidippa sp. & 174 & Portunus trituberculatus \\
\hline 105 & Eunice indica & 140 & Lembos clavatus & 175 & Heteroplax nitida \\
\hline 106 & Lumbrineris latreilli & 141 & Photis sp. & 176 & Hemigrapsus penicillatus \\
\hline 107 & Scoletoma longifolia & 142 & Gammaropsis utinomii & 177 & Perisesarma bidens \\
\hline 108 & Scoletoma nipponica & 143 & Unidentified Isaeidae & 178 & Macrophthalmus japonicus \\
\hline 109 & Scoletoma sp. & 144 & Siphonocoetes sp. A & 179 & Macrophthalmus banzai \\
\hline 110 & Schistomeringos sp. & 145 & Siphonocoetes sp. B & \multicolumn{2}{|c|}{ Echinoidea } \\
\hline 111 & Myriochele sp. & 146 & Corophium acherusicum & 180 & Unidentified Laganidae \\
\hline 112 & Flabelligera sp. & 147 & Ericthonius pugnax & 181 & Echinocardium cordatum \\
\hline 113 & Lagis sp. & 148 & Protomima imitatrix & \multicolumn{2}{|c|}{ Holothuroidea } \\
\hline 114 & Amphitrite sp. & 149 & Caprella californica & 182 & Leptosynapta inhaerens \\
\hline 115 & Lysippe sp. & 150 & Caprella gigantochir & 183 & Patinapta ooplax \\
\hline 116 & Nicolea sp. & 151 & Caprella rhopalochir & 184 & Unidentified Synaptidae \\
\hline & Eupolymnia sp. & \multicolumn{2}{|c|}{ Isopoda } & 185 & Myriotrochus sp. \\
\hline 118 & Polycirrus sp. & 152 & Ianiropsis serricaudis & \multicolumn{2}{|c|}{ Ascidiacea } \\
\hline & Streblosoma sp. & 153 & Unidentified Anthuridae & 186 & Adagnesia vesiculiphora \\
\hline & Euchone sp. & \multicolumn{2}{|c|}{ Tanaidacea } & 187 & Unidentified Molgulidae \\
\hline & Potamilla sp. A & 154 & Leptochelia sp. & \multicolumn{2}{|c|}{ Leptocardia } \\
\hline 122 & Potamilla sp. B & 155 & Zeuxo sp. & 188 & Branchiostoma belcheri \\
\hline \multicolumn{2}{|c|}{ Pycnogonida } & \multicolumn{2}{|c|}{ Cumacea } & \multicolumn{2}{|c|}{ Osteichthyes } \\
\hline 123 & Unidentified Callipallenidae & 156 & Bodotria sp. & 189 & Chaenogobius castaneus \\
\hline \multicolumn{2}{|c|}{ Ostracoda } & 157 & Dimorphostylis elegans & 190 & Pseudogobius masago \\
\hline 124 & Cypridina sp. & 158 & Dimorphostylis sp. A & 191 & Favonigobius gymnauchen \\
\hline 125 & Unidentified Ostracoda & 159 & Dimorphostylis sp. B & 192 & Mugilogobius abei \\
\hline \multicolumn{2}{|c|}{ Phyllocarida } & \multicolumn{2}{|c|}{ Decapoda } & 193 & Acentrogobius pfaumii \\
\hline 126 & Nebalia japanensis & 160 & Leptochela aculeocaudata & 194 & Tridentiger obscurus \\
\hline
\end{tabular}

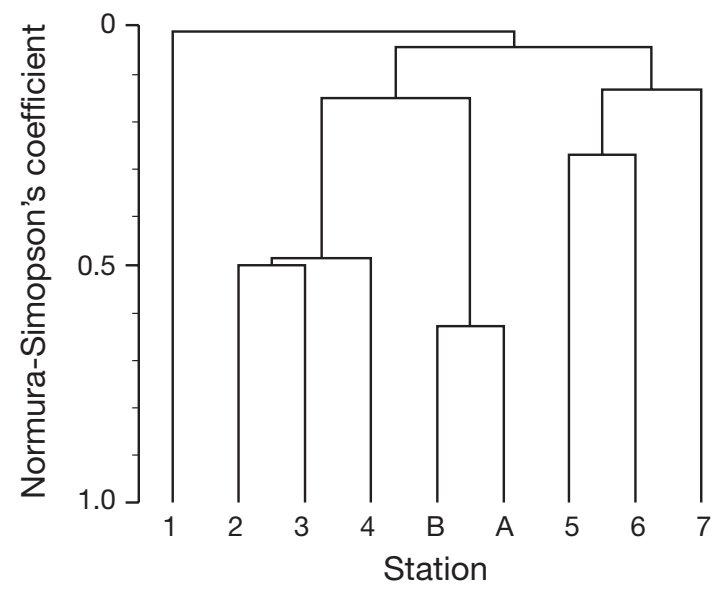

Fig. 4. Cluster analysis of the macrobenthos collected from 9 stations, based on the Nomura-Simpson's coefficient
There were significant differences between the $\delta^{13} \mathrm{C}$ values of intertidal consumers (Stn 1) and those of subtidal consumers collected from Stns 2 to 7 (Steel-Dwass test, all $\mathrm{p}<0.01$, Table 2). The intertidal consumers had a wide range of $\delta^{13} \mathrm{C}(-21.2$ to $-10.9 \%)$. These consumers displayed a bimodal frequency distribution with modes at -18 to $-17 \%$ and -15 to $-12 \%$, resulting in the separation of 2 groups, viz. a group having reduced $\delta^{13} \mathrm{C}$ values of $<-17 \%$ (group $\mathrm{A}$ ), and a group having enriched $\delta^{13} \mathrm{C}$ values of $>-17 \%$ (group B) (Fig. 6a). Group A was mainly composed of bivalves $(28,35,37,39,40,42,44$ [all species numbers here and following are listed in Table 1], Fig. 5), while group B was composed of a variety of taxa including gastropods $(10,12$ to 16,19$)$, polychaetes $(73,98,108)$, decapods $(161,163,170,171,173,174,176,178,179)$, a holothurian (183) and osteichthyans (189 to 194). 
At the subtidal stations, consumers having enriched $\delta^{13} \mathrm{C}$ values of $>-14 \%$ o were absent. Frequency distributions of $\delta^{13} \mathrm{C}$ at these stations are unimodal, centered on a mode of -17 to $-16 \%$ or -18 to $-17 \%$ o (Fig. 6a). Macrofauna at Stn 2 was characterized by the occurrence of 9 consumers $(4,31$, $66,92,94,99,107,162,166)$ having relatively enriched $\delta^{13} \mathrm{C}$ values (-16 to $-14 \%$ o). Macrofauna at the other subtidal stations (Stns 3 to 7 ) lacked consumers having $\delta^{13} \mathrm{C}$ values of $>-16 \%$, except for 2 species $(7,30)$ collected from Stn 5. Remarkably depleted values of the $\delta^{13} \mathrm{C}$ found at Stns $4(-34.1 \%$ o) and $5(-27.7 \%)$ were due to the occurrence of the bivalve Petrasma pusilla (23).

The $\delta^{15} \mathrm{~N}$ of the consumers collected from Stns 1, 2 and 3 ranged from 6.4 (35: Peregrinamor ohshimai) to $11.7 \%$ (192: Mugilogobius abei), from 6.7 (162: Athanas japonicus) to $12.0 \%$ (99: Glycera nicobarica) and from 7.6 (34: Theora lubrica) to $12.1 \%$ (G. nicobarica), respectively. If the remarkably depleted $\delta^{15} \mathrm{~N}$ value of Petrasma pusilla $(-6.7 \%$ ) is excluded, consumers found at Stn 4 exhibited a range in $\delta^{15} \mathrm{~N}$ from 7.1 to $12.0 \%$ o (range $=4.9 \%$ ), similar to ranges at Stns 1 to 3 (range $=4.5$ to $5.3 \%$ ). Toward the offshore station, the range of $\delta^{15} \mathrm{~N}$ for consumers increased (i.e. $7.2 \%$ at $\operatorname{Stn} 5$ if $-1.7 \%$ for $P$. pusilla is excluded, 8.2\% at Stn 6 and $9.1 \%$ at Stn 7), mainly due to a decline of the minimum value at each station (i.e. $5.7 \%$ o for Ampelisca naikaiensis [130] at Stn 5, $4.1 \%$ for Limatula vladivostokensis [27] at Stn 6 and 3.7\%o for Euchone sp. [120] at Stn 7 ). The large range of $\delta^{15} \mathrm{~N}$ values at Stn 7 resulted in significant differences between Stn 7 and Stns 1, 3, 4 and B (Table 3: Steel-Dwass test, all $\mathrm{p}<0.05)$.

There were significant differences in $\delta^{13} \mathrm{C}$ of consumers between the fishfarm stations (Stns A, B) and most of the other stations (between Stn A and Stns 1, 2, 4 to 7; between Stn B and Stns 1, 2, 5, 6: Table 2, Steel-Dwass test, all $\mathrm{p}<0.05)$. Of the $55 \delta^{13} \mathrm{C}$ measurements of the consumers obtained from the fish farming stations, 42 (including the values for the dominant species, viz. Pseudopolydora paucibranchiata [64], Capitella sp. [78],
Schistomeringos sp. [110] and Nebalia japanensis [126]) fell within a range of -21 to $-18 \%$, showing much reduced $\delta^{13} \mathrm{C}$ values in comparison with the other subtidal consumers.

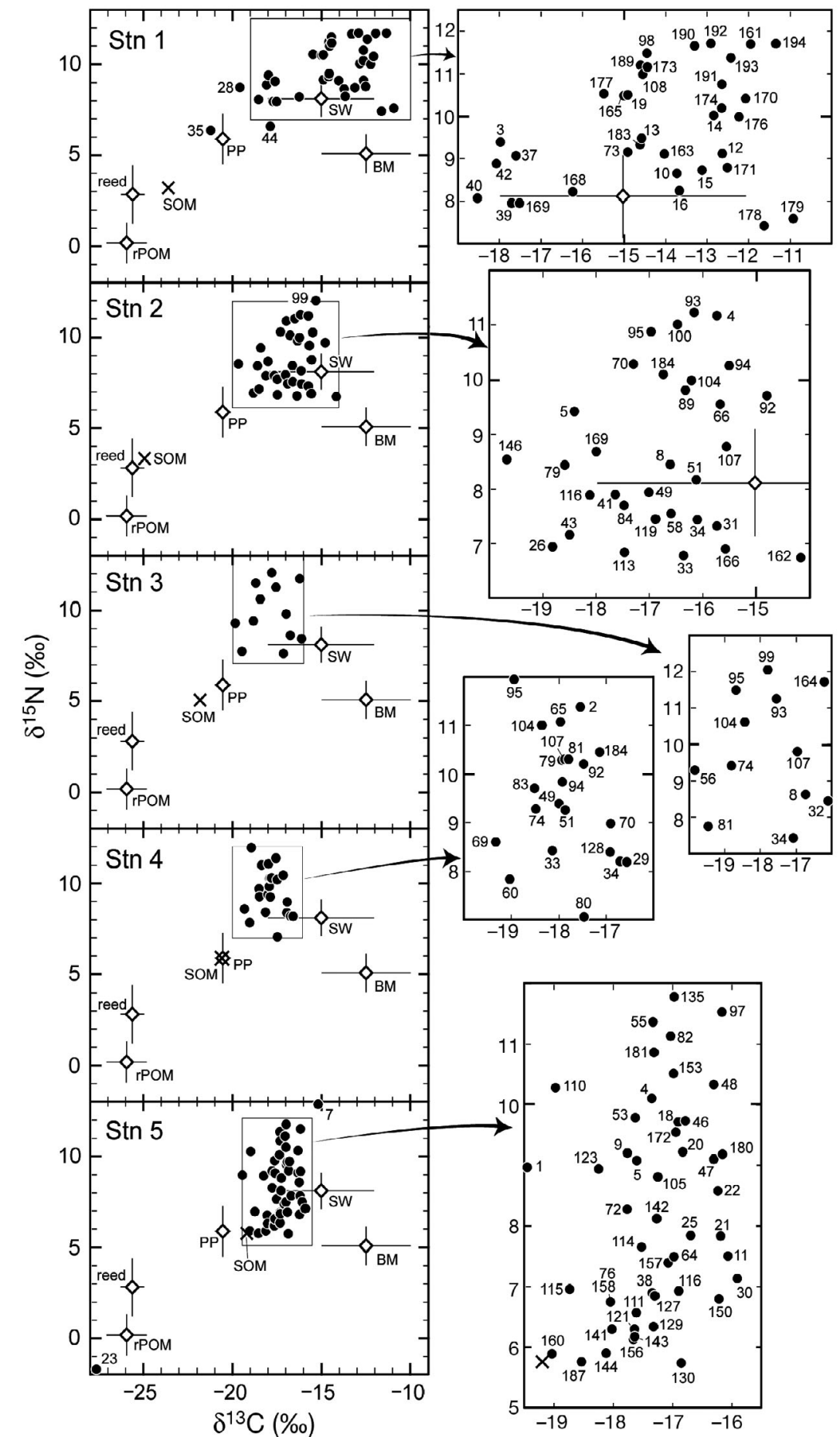

Fig. 5. Dual isotope plots of $\delta^{13} \mathrm{C}$ vs. $\delta^{15} \mathrm{~N}$ for consumers and their potential food sources at 9 stations. See Table 1 for species' numbers (1 through 194). rPOM: riverine particulate organic matter; PP: coastal phytoplankton; BM: benthic microalgae; SW: seaweeds; SOM: sedimentary organic matter.

(Figure continued on next page) 


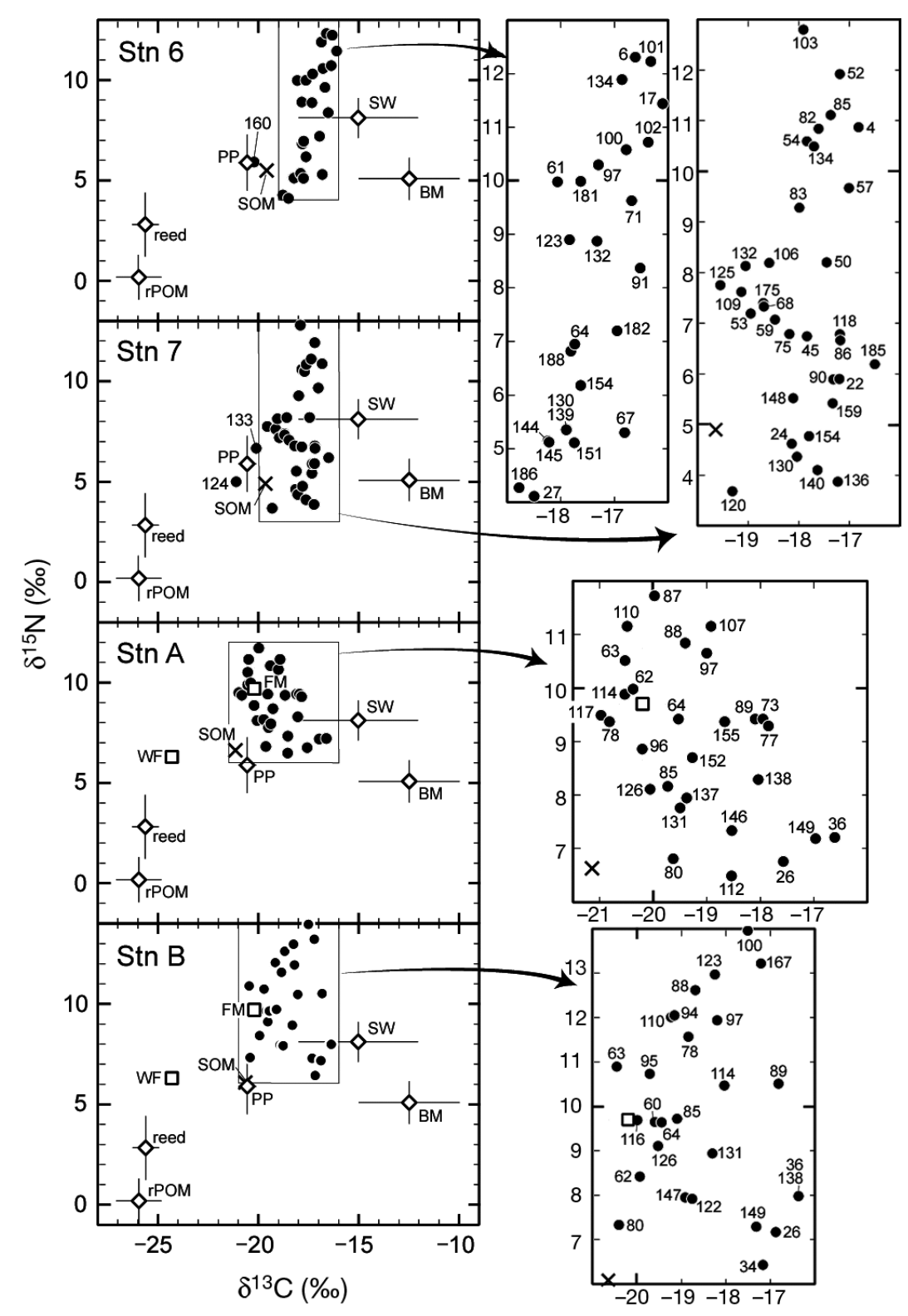

Fig. 5 (continued)

The $\delta^{15} \mathrm{~N}$ of consumers at Stn A ranged from 6.5\% (112: Flabelligera sp.) to $11.7 \%$ (87: Anaitides sp. B) (range $=5.2 \%$ ), while the consumers at Stn B spanned a wider range $(7.6 \%)$, due to the occurrence of Glycera sp. $\left(100, \delta^{15} \mathrm{~N}=14.0 \%\right.$ o).

\section{Between-site differences in $\delta^{13} \mathrm{C}$ and $\delta^{15} \mathrm{~N}$ values for consumer species}

Among species identified to the genus or species level, 30 appeared at 2 or 3 stations along the transect (Stns 1 to 7 ). Fig. 7 shows the spatial variations of the $\delta^{13} \mathrm{C}$ and $\delta^{15} \mathrm{~N}$ values for these species except for the bivalve Petrasma pusilla, which exhibited remarkably depleted $\delta^{13} \mathrm{C}$ and $\delta^{15} \mathrm{~N}$ values. All 6 species that co-occurred at Stns 2 and 3 (Theora lubrica [34], Gyptis sp. [93], Sigambra phuketensis [95], Glycera nicobarica [99], Nephtys oligobranchia [104], Scoletoma longifolia [107]) had more depleted $\delta^{13} \mathrm{C}$ values at Stn 3. Of 11 species that cooccurred at Stns 2 and 4, 9 species (Macoma incongrua [33], T. lubrica, Phylo sp. [49], Scoloplos (Scoloplos) sp. [51], Sthenolepis sp. [92], Ophiodromus sp. [94], Sigambra phuketensis, N. oligobranchia and Scoletoma longifolia) had more depleted $\delta^{13} \mathrm{C}$ values at $\mathrm{Stn} 4$. The observed shifts in the $\delta^{13} \mathrm{C}$ between Stns 2 and 3 and between Stns 2 and 4 are statistically significant (Table 4: paired $t$-test, both $\mathrm{p}<0.005)$. The decreasing trend in the $\delta^{13} \mathrm{C}$ toward the offshore station were also found in the seaward area (Stn 5 to 7), showing significant differences between Stns 5 and 6 and between Stn 5 and 7 (paired $t$-test, both $\mathrm{p}<$ 0.01). In this area, Pulsellum hige (22), Aricidea simplex (53), Glycera alba (97), Ampelisca naikaiensis (130) and Leptochela aculeocaudata (160) all had $>1 \%$ decrease in the $\delta^{13} \mathrm{C}$ values from landward to seaward stations.

Of 18 species collected from the inner part of the bay (Stns 1 to 4), 11 (Macoma incongrua [33], Theora lubrica [34], Pylo sp. [49], Scoloplos (Scoloplos) sp. [51], Heteromastus sp. [79], Notomastus sp. A [81], Sthenolepis sp. [92], Sigambra phuketensis [95], N. oligobranchia [104] and Scoletoma longifolia [107], Upogebia major [169]) showed an increase in $\delta^{15} \mathrm{~N}$ from landward to seaward (Fig. 7b). The difference in $\delta^{15} \mathrm{~N}$ between Stn 2 and Stn 4 was significant (Table 4: paired $t$-test, $\mathrm{p}<0.05$ ). By contrast, the majority of species that occurred in the mouth of the bay to the offshore area (Stns 5 to 7 ) had decreasing $\delta^{15} \mathrm{~N}$ values from landward to seaward. Species that showed a large spatial variation $\left(\Delta \delta^{15} \mathrm{~N}>1 \%\right.$ ) include Pulsellum hige (22), Aricidea simplex (53), Glycera alba (97), Ampelisca naikaiensis (130), Harpiniopsis sp. (134) and Leptochelia sp. (154). The differences in $\delta^{15} \mathrm{~N}$ between Stn 5 and 6 and between Stn 6 and 7 are significant (paired $t$-test, both $\mathrm{p}<0.05$ ). 
(a)

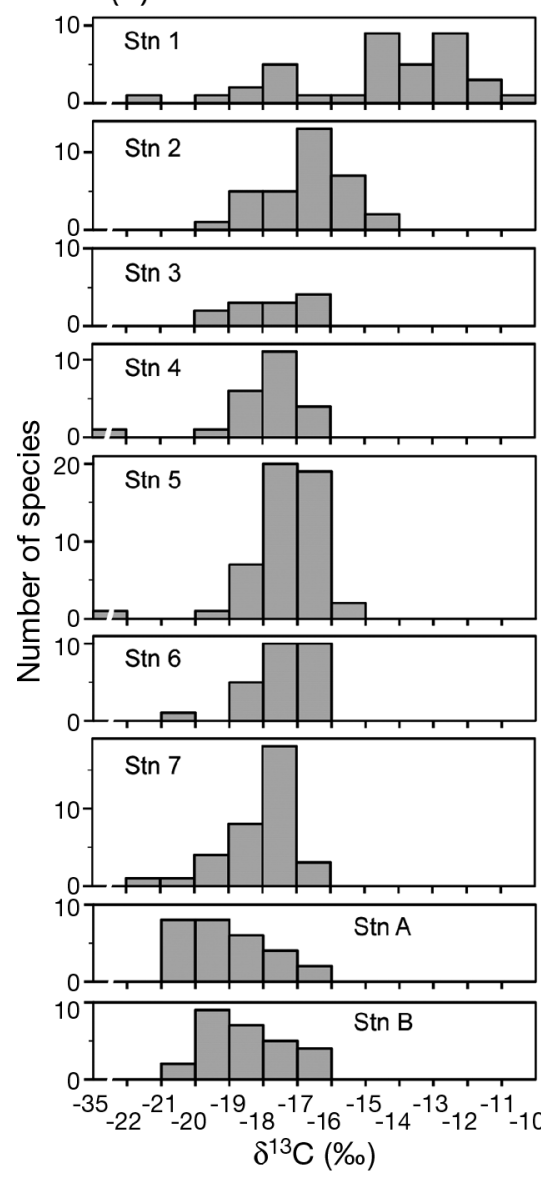

(b)
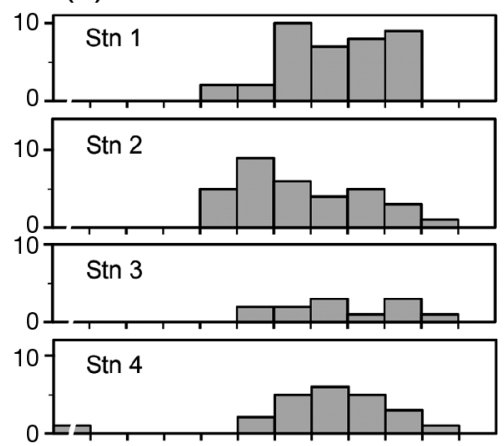

$2 0 \longdiv { \operatorname { S t n } 5 }$
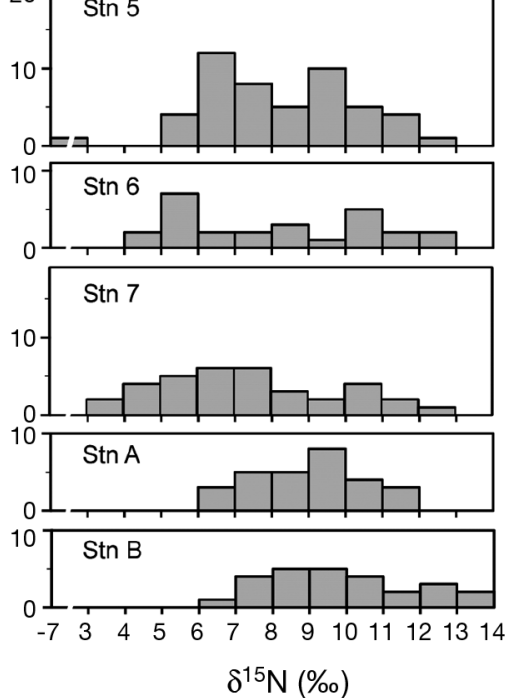

Fig. 6. (a) Frequency distributions of $\delta^{13} \mathrm{C}$ and (b) frequency distributions of $\delta^{15} \mathrm{~N}$ for consumers at 9 stations

Table 2. $t$-values of Steel-Dwass post-hoc test for pairwise differences in the $\delta^{13} \mathrm{C}$ of benthic animals between stations

\begin{tabular}{|lllllllll|}
\hline & Stn 1 & Stn 2 & Stn 3 & Stn 4 & Stn 5 & Stn 6 & Stn 7 & Stn A \\
\hline Stn 2 & $4.03^{* *}$ & & & & & & & \\
Stn 3 & $3.57^{* *}$ & 2.35 & & & & & & \\
Stn 4 & $4.65^{* * *}$ & $3.60^{* *}$ & 0.50 & & & & & \\
Stn 5 & $4.89^{* * *}$ & 2.40 & -1.09 & -2.72 & & & & \\
Stn 6 & $4.37^{* * *}$ & 2.57 & -0.64 & -1.97 & 0.84 & & & \\
Stn 7 & $5.23^{* * *}$ & $4.24^{* * *}$ & 0.77 & 0.17 & $3.35^{*}$ & 2.11 & & \\
Stn A & $5.91^{* * *}$ & $5.55^{* * *}$ & 2.85 & $3.58^{* *}$ & $5.55^{* * *}$ & $4.63^{* * *}$ & $3.70^{* *}$ & \\
Stn B & $5.37^{* * *}$ & $4.54^{* * *}$ & 1.66 & 1.82 & $3.90^{* *}$ & $3.12^{*}$ & 1.71 & -1.93 \\
& & & & & & & & \\
${ }^{*} \mathrm{p}<0.05,{ }^{* *} \mathrm{p}<0.01^{* * *} \mathrm{p}<0.001$ & & & & & \\
\hline
\end{tabular}

Fig. 8 shows the $\delta^{13} \mathrm{C}$ and $\delta^{15} \mathrm{~N}$ values for samples of the same species that occurred inside (Stn A, B) and outside (Stns 1 to 7 ) the fish-farm area. The $\delta^{13} \mathrm{C}$ of consumers inside the fish farm was significantly more enriched than the $\delta^{13} \mathrm{C}$ outside the farm (paired $t$-test, df = $14, t=4.28, \mathrm{p}<0.001)$. Of 16 species analyzed, 14 showed reduced $\delta^{13} \mathrm{C}$ values at the fish-farm stations
$\left(\Delta \delta^{13} \mathrm{C}=-0.5\right.$ to $-3.0 \%$ ). In particular, the polychaetes Pseudopolydora paucibranchiata, Cirriformia sp., Mediomastus sp., Armandia sp., Ophiodromus sp., Glycera alba, Scoletoma longifolia and Nicolea sp. collected at the fish farm were reduced in $\delta^{13} \mathrm{C}$ by $>2 \%$. On the other hand, at the fish-farm stations, 7 of the 16 species, including the dominant or subdominant taxa such as $P$. paucibranchiata, Ophiodromus sp., S. longifolia and Schistomeringos sp. showed an increase in $\delta^{15} \mathrm{~N}\left(\Delta \delta^{15} \mathrm{~N}=1.4\right.$ to $2.5 \%$ ) Four species showed a decrease $\left(\Delta \delta^{15} \mathrm{~N}=\right.$ -2.2 to $-0.7 \%$ o), and 5 species showed no obvious trends $\left(\Delta \delta^{15} \mathrm{~N}=0\right.$ to $0.4 \%$ ).

\section{DISCUSSION}

\section{Food sources of intertidal consumers}

The $\delta^{13} \mathrm{C}$ values of the intertidal consumers at Stn 1 were very different from those of riverine POM and reed (>5\% difference), suggesting that these sources of terrestrial organic matter (TOM) scarcely contribute to the diet of the consumers, although intertidal sediments contain a good deal of TOM. Because TOM is usually rich in refractory compounds such as cellulose and lignin, its nutritional value for coastal animals is considered to be small (Cividanes et al. 2002). Taking into account the considerable distance from the fish farm $(>3 \mathrm{~km})$ and the dispersal range of aquaculturederived particulate organic matter $(<300 \mathrm{~m}$ from the fish cage, Yokoyama et al. 2006), such organic matter appears not to be used by intertidal animals directly. Many intertidal consumers had $\delta^{13} \mathrm{C}$ values close to that of seaweeds. Among them, primary consumers including herbivorous gastropods $(10,15$, 16) and suspension or deposit feeding decapods $(168,169,178,179)$ had $\delta^{15} \mathrm{~N}$ values that were the same levels as or enriched only by $<1 \%$ relative to seaweeds. Given a presumptive 2 to $4 \%$ o trophic shift in the $\delta^{15} \mathrm{~N}$ value of consumers, seaweeds appear to play a smaller role in the diet of intertidal animals than other primary producers. The scarcity of living and stranded seaweeds also suggests that they do not make a significant contribution. The $\delta^{13} \mathrm{C}$ values of the intertidal consumers fell 
Table 3. $t$-values of Steel-Dwass post-hoc test for pairwise differences in the $\delta^{15} \mathrm{~N}$ of benthic animals between stations

\begin{tabular}{|lrrrrrrrr|}
\hline & Stn 1 & Stn 2 & Stn 3 & Stn 4 & Stn 5 & Stn 6 & Stn 7 & Stn A \\
\hline Stn 2 & 2.26 & & & & & & & \\
Stn 3 & -0.55 & -2.02 & & & & & & \\
Stn 4 & 0.35 & -1.67 & 0.80 & & & & & \\
Stn 5 & $3.22^{*}$ & 1.40 & 2.61 & 2.54 & & & & \\
Stn 6 & 2.20 & 1.18 & 1.87 & 1.58 & 0.61 & & & \\
Stn 7 & $3.97^{* *}$ & 2.87 & $3.17^{*}$ & $3.16^{*}$ & 1.77 & 0.72 & & \\
Stn A & 1.36 & -0.51 & 1.45 & 0.98 & -1.89 & -1.33 & -2.98 & \\
Stn B & -0.59 & -2.17 & -0.05 & -0.73 & $-3.21^{*}$ & -2.55 & $-3.81^{* *}-1.71$ \\
& & & & & & & & \\
${ }^{*} \mathrm{p}<0.05,{ }^{* *} \mathrm{p}<0.01$ & & & & & & & \\
\hline
\end{tabular}
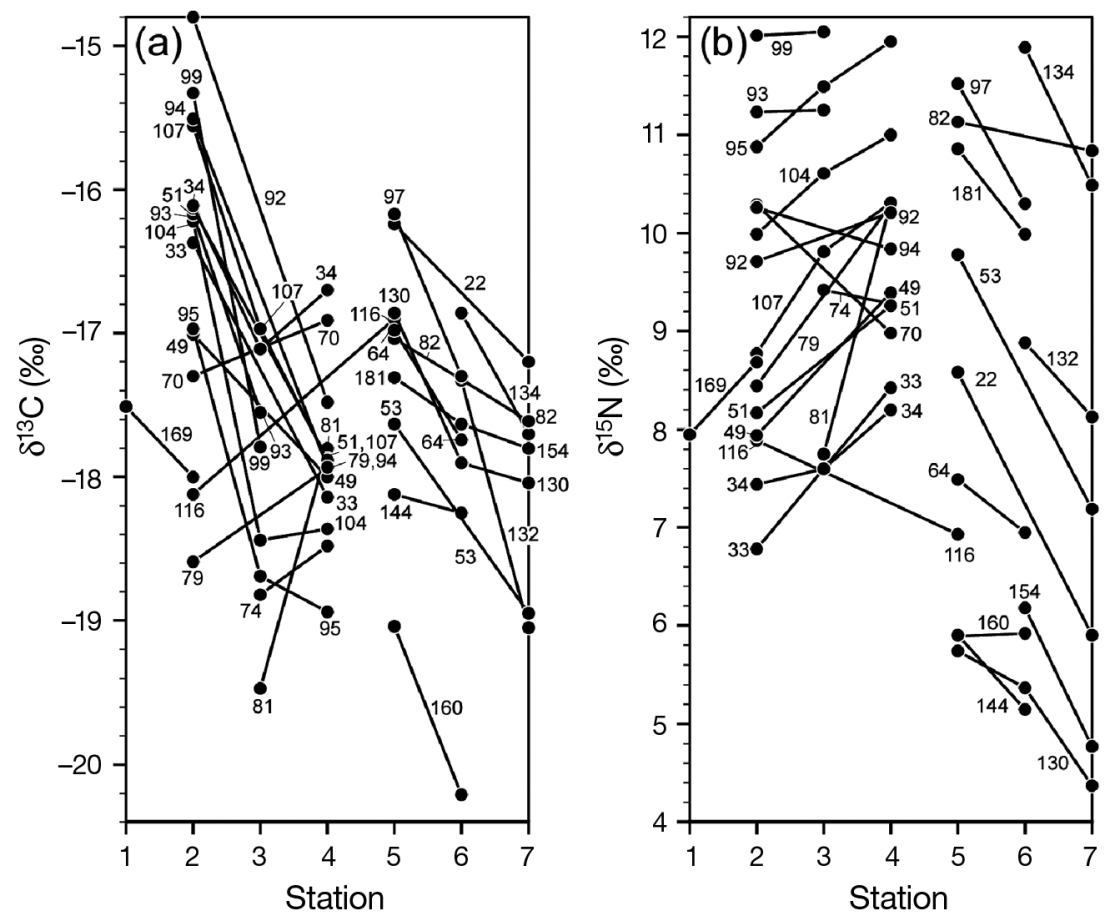

Fig. 7. (a) $\delta^{13} \mathrm{C}$ and (b) $\delta^{15} \mathrm{~N}$ values for samples of the same species collected from the transect (Stns 1 to 7 ). See Table 1 for species' numbers

Table 4. Paired $t$-test for differences between pairs of stations sharing species

\begin{tabular}{|c|c|c|c|c|c|c|}
\hline \multirow[t]{2}{*}{ Stations } & \multicolumn{3}{|c|}{$\delta^{13} \mathrm{C}$} & \multicolumn{3}{|c|}{$-\delta^{15} \mathrm{~N}$} \\
\hline & $\mathrm{df}$ & $t$ & $\mathrm{p}$ & $\mathrm{df}$ & $t$ & $\mathrm{p}$ \\
\hline Stns 2 and 3 & 5 & 7.54 & $<0.001$ & 5 & 2.49 & 0.055 \\
\hline Stns 2 and 4 & 10 & 4.14 & 0.002 & 10 & 2.92 & 0.015 \\
\hline Stns 3 and 4 & 5 & 0.64 & 0.551 & 5 & 1.91 & 0.115 \\
\hline Stns 5 and 6 & 5 & 4.19 & 0.009 & 5 & 3.52 & 0.017 \\
\hline Stns 5 and 7 & 3 & 6.18 & 0.009 & 3 & 3.06 & 0.055 \\
\hline Stns 6 and 7 & 3 & 1.92 & 0.150 & 3 & 7.04 & 0.006 \\
\hline
\end{tabular}

between the $\delta^{13} \mathrm{C}$ values for coastal phytoplankton (PP) and those of benthic microalgae (BM). The $\delta^{15} \mathrm{~N}$ values for consumers were $>2.5 \%$ enriched relative to $\mathrm{PP}$ and $\mathrm{BM}$, except for the bivalve Peregrinamor ohshimai (35), which is an ectoparasite on the mud shrimp Upogebia major. These findings suggest that the majority of intertidal consumers derive their nutrition from a mixture of PP and BM, and allow the calculation of the contribution ratios (CR) of these microalgae to the diet of consumers using the dual isotope model (Yokoyama et al. 2002) (Fig. 9).

The intertidal consumers were roughly divided into group $\mathrm{A}\left(\delta^{13} \mathrm{C}<\right.$ $-17 \%$ ) and group $\mathrm{B}\left(\delta^{13} \mathrm{C}>-17 \%\right)$. Members of group A depend mainly on PP (CR of PP = 71 to $96 \%$ ). Group A comprises the suspension feeding bivalves $(28,37,39,40,42)$ and mud shrimp (169), and the unidentified flatworm (3). The $\delta^{15} \mathrm{~N}$ value of the flatworm was more enriched than those of the bivalves, suggesting that this species preys on bivalves. Consumers that depend mainly on BM ( $\mathrm{CR}$ of $\mathrm{BM}=67$ to $100 \%$ ) are members of group B. Among them, the gastropods $(10,12,14,15,16)$ are those that graze on BM growing on sediment or stone surfaces. The BMdependent decapods include the herbivorous ocypodid crabs (178, 179), which use BM as their sole food source $(\mathrm{CR}$ of $\mathrm{BM}=96$ to $100 \%)$, and omnivores and carnivores such as the hermit crabs $(170,171)$, portunid crab (174) and grapsid crab (176), which showed enriched $\delta^{15} \mathrm{~N}$ values $(8.8$ to $10.4 \%$ ) corresponding to higher trophic levels than the ocypodid crabs $\left(\delta^{15} \mathrm{~N}=7.4\right.$ to $7.6 \%$ ). The carnivorous gobies (190 to 194) and shrimp (161) are at the highest trophic level in this tidal flat, with 5.7 to $6.6 \%$ enrichment relative to the $\delta^{15} \mathrm{~N}$ for $\mathrm{BM}$, which suggests that the benthic food web in this area is composed of 3 trophic levels and that BM is an indirect food source for these carnivores via intermediate prey.

Group B also includes consumers that incorporate a mixture of PP and BM (CR of BM = 37 to $59 \%$ ). They are composed of the gastropods $(13,19)$, polychaetes $(73,98,108)$, decapod crustaceans $(163,165,168,173)$, 


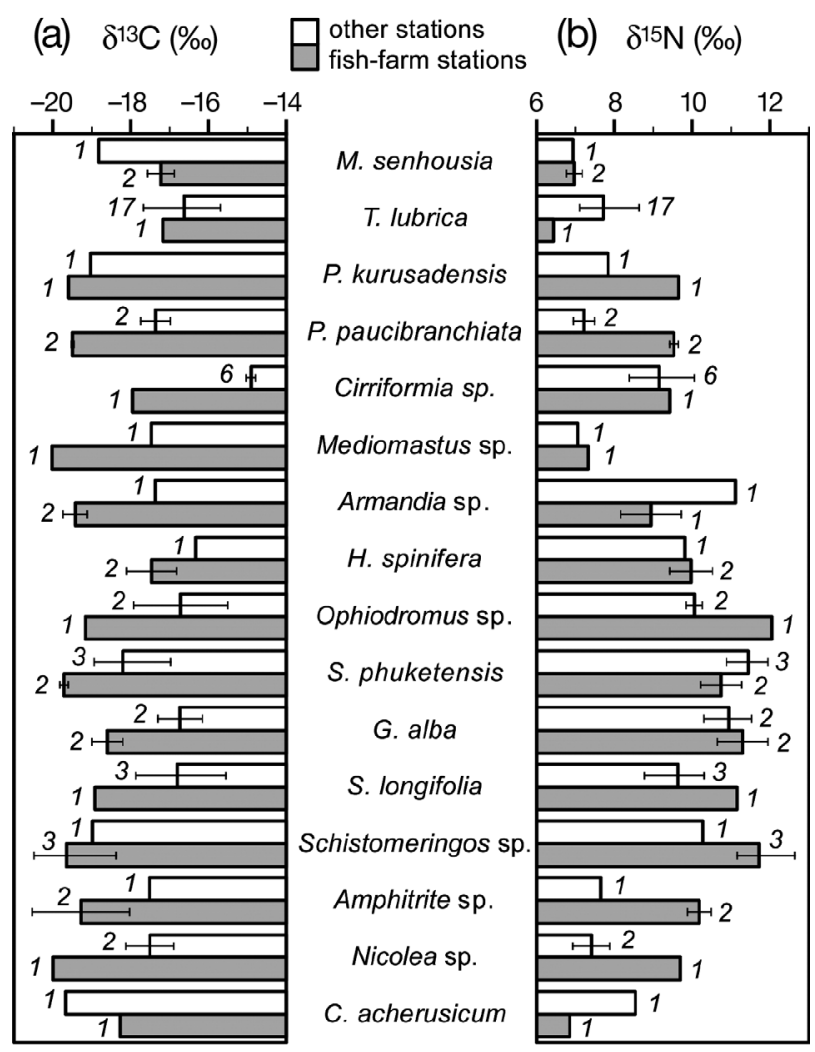

Fig. 8. (a) $\delta^{13} \mathrm{C}$ and (b) $\delta^{15} \mathrm{~N}$ values for 15 species collected from the inside and outside the fish-farm area. Error bars are the range of values. Numerals in italics indicate sample size (n). See Table 1 for full generic names abbreviated here to single letters

holothurian (183) and goby (189). Among them, consumers $(13,73,163,168,183)$ having depleted $\delta^{15} \mathrm{~N}$ values (8.2 to $9.5 \%$ ) are considered to be herbivores or deposit feeders, while enriched $\delta^{15} \mathrm{~N}$ values (10.5 to $11.5 \%$ o) of the other consumers $(19,98,108,165,173$, 189) suggest that they are omnivores or carnivores. Herman et al. (2000) suggested that the interface feeders (the bivalve Macoma balthica and the polychaete Pygospio elegans) ingest fecal biodeposits of suspension feeders as well as BM, resulting in $\delta^{13} \mathrm{C}$ values of these animals intermediate between PP and BM. The deposit feeders in the study area probably exhibit a similar feeding strategy. On the other hand, BM supply 20 to $30 \%$ of the diet for the suspension feeding bivalves. Kasai et al. (2004) estimated the contribution ratios of PP (55\%), BM (33\%) and TOM (12\%) to the diet of the suspension feeding bivalves Ruditapes philippinarum and Mactra veneriformis inhabiting the Miya River estuary, Japan. In contrast, Yokoyama et al. (2005b) reported that PP is the sole food source of these 2 bivalves living on the sandflat in Ariake Sound, where the BM biomass is small. Kanaya et al. (2005) found the diet of $R$. philippinarum changed from PP in the natural habitat to BM under experimental enclosure conditions. In the present study area, R. philippinarum (40) uses a higher proportion of PP (80\%) compared to BM (20\%). Thus, the relative importance of PP and BM for suspension feeders could vary, probably depending on the local primary productivity and the intensity of resuspension of BM.

\section{Shift in food sources along the transect}

The present study showed that the $\delta^{13} \mathrm{C}$ values for the subtidal consumers also fell between the values of coastal phytoplankton (PP) and benthic microalgae (BM), suggesting that these animals obtain their nutrition mainly from microalgae. The large difference in $\delta^{13} \mathrm{C}$ between riverine terrestrial organic matter (TOM) and subtidal consumers $(>7 \%$ ) implies that TOM was not a significant source of the carbon. The $\delta^{15} \mathrm{~N}$ values for seaweeds $(8.1 \pm 2.9 \%$, mean $\pm \mathrm{SD})$ were similar to (or more enriched than) those for primary consumers (ca. 4 to $8 \%$ ). Assuming a 2 to $4 \%$ shift in $\mathrm{N}$ assimilation per trophic level, seaweeds were probably not important in the diet of the consumers. Aquaculturederived organic matter also was not a major component of the diet, because (1) $\delta^{13} \mathrm{C}$ values for fish feces were at least $4 \%$ more depleted, and (2) $\delta^{15} \mathrm{~N}$ values for waste feed were more enriched than those for the majority of consumers. The present study also showed significant differences in the frequency distributions of $\delta^{13} \mathrm{C}$ and $\delta^{15} \mathrm{~N}$ values for the consumers between the stations, suggesting that the relative importance of PP and BM to subtidal consumers shifted along the transect. Using the conservative mixing model, Fry (2002) showed that marked changes in stable isotope values of dissolved inorganic carbon occur across estuarine salinity gradients. This model indicates an increase in
Fig. 9. Relative dependence of consumers on coastal phytoplankton and benthic microalgae in the intertidal habitat. Contribution ratios $(\mathrm{CR})$ of the 2 food sources were calculated based on Yokoyama et al. (2002). See Table 1 for species' numbers

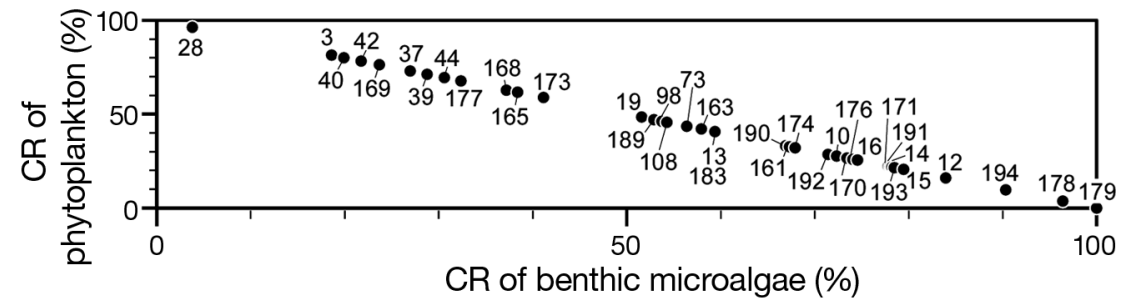


algal $\delta^{13} \mathrm{C}$ in the offshore direction. However, the observed $\delta^{13} \mathrm{C}$ of the consumers in our study area showed the opposite trend, suggesting a changing food source.

The dual isotope model was also applied to describe the relative importance of PP and BM (Fig. 10). For convenience of explanation, consumers are classified into a group in which the contribution of PP exceeds $\mathrm{BM}$ (CR of PP $>66 \%$ ), a group in which the contribution of BM exceeds PP (CR of BM > 66\%) and a group in which the algal source contributions are equivalent (CR of PP or MB = 34 to $66 \%$ ). In Fig. 10, the groups are denoted as 'phytoplankton-dependent species', 'benthic microalgae-dependent species' and 'mixturedependent species', respectively. Consumers with an estimated diet-tissue ${ }^{15} \mathrm{~N}$ fractionation of $<0.8 \%$ are excluded from classification into any of the 3 groups and are denoted as 'unknown'. The solemyid bivalve Petrasma pusilla collected from the central part of the bay (Stns 4,5$)$ had extraordinarily depleted $\delta^{13} \mathrm{C}$ $\left(-34.1\right.$ to $-27.7 \%$ ) and $\delta^{15} \mathrm{~N}$ values $(-6.7$ to $-1.7 \%$ ), which are considered to reflect chemosynthesis by endosymbiotic sulfur bacteria (Imhoff et al. 2003). Conway et al. (1992) reported a similar range of $\delta^{13} \mathrm{C}$ $\left(-34.6\right.$ to $-30.9 \%$ ) and $\delta^{15} \mathrm{~N}(-9.8$ to $4.4 \%$ o) values for Petrasma borealis and P. velum. In Fig. 10, P. pusilla is shown as 'chemosynthesis species'. In the intertidal habitat (Stn 1), the BM-dependent species predominated, comprising $45 \%$ (vs $24 \%$ PP-dependent species) of total number of species analyzed (Fig. 10). At subtidal Stn 2 that was located close to the tidal flat, the BM-dependent species group comprised only the

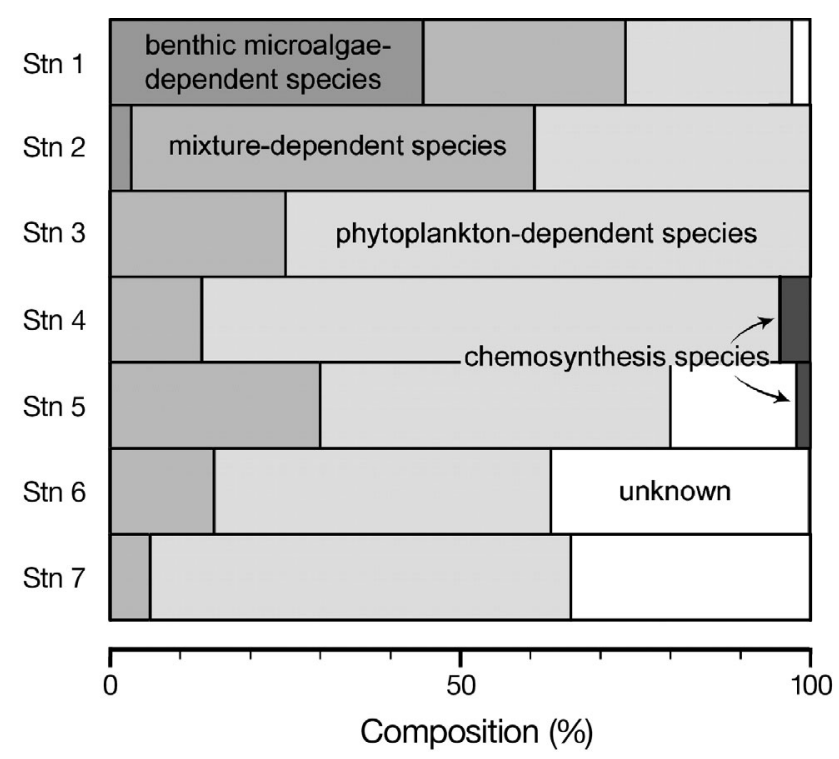

Fig. 10. Proportion of 5 trophic groups at 7 stations along the transect. See text for the classification of the trophic groups shrimp Athanas japonicus (162), whereas the PPdependent species group accounted for $39 \%$ of total number of taxa. At this station (Stn 2), however, the mixture-dependent species accounted for the largest proportion $(58 \%)$, indicating that $\mathrm{BM}$ are still an important component of the food web. With increasing distance from the head of the bay, the proportion of PPdependent species increased rapidly reaching $>48 \%$ at Stns 3 to 7, whereas BM-dependent species disappeared, and even the mixture-dependent consumers accounted for only $6 \%$ at the most offshore station (Stn 7). The decreasing trend in the $\delta^{13} \mathrm{C}$ within single species from landward to seaward also suggests the change of food source from BM to PP.

In the seaward area (Stns 5 to 7 ), consumers with depleted $\delta^{15} \mathrm{~N}$ values of $<6.7 \%$ o were found. In addition to this, there was a decreasing trend from landward to seaward in the $\delta^{15} \mathrm{~N}$ within single species. Two possible explanations exist for the depletion of $\delta^{15} \mathrm{~N}$ values in consumers. First, the ${ }^{15} \mathrm{~N}$ diet-tissue fractionation values of crustaceans whose whole bodies were sampled were found to be more reduced than the values for species whose muscle tissues only were sampled. Chitin included in the whole body samples is a major component of exoskeletons, and is depleted in ${ }^{15} \mathrm{~N}$ by 6.6 to $9.5 \%$ relative to diet (DeNiro \& Epstein 1981, Schimmelmann \& DeNiro 1986). Of the 33 measurements of $\delta^{15} \mathrm{~N}$ with values $<6.7 \%$ from Stns 5 to 7,19 were obtained from whole body analyses (including exoskeletons) of small crustaceans such as amphipods, cumaceans, tanaids and ostracods; these whole body estimates may have resulted in low $\delta^{15} \mathrm{~N}$ values for these consumers. The second explanation is based on the assumption that there is a discrepancy between the observed phytoplankton $\delta^{15} \mathrm{~N}$ and the value for organic matter incorporated by animals inhabiting the offshore sandy bottom. The $\delta^{15} \mathrm{~N}$ value for the sedimentary organic matter shifted from $5.9 \%$ at Stn 5 to $4.9 \%$ at Stn 7 (Fig. 2), suggesting that sinking and deposited particles in the offshore area had more reduced $\delta^{15} \mathrm{~N}$ values than the $\delta^{15} \mathrm{~N}$ for PP $(5.9 \%$ ), which was determined from POM samples collected in surface seawater at Stn 5 (Yokoyama \& Ishihi 2003). Considering that there is no possible source of organic matter other than PP in this area, the consumers whose food source is shown as 'unknown' in Fig. 10 seem to gain their nutrition mainly from $\mathrm{PP}$, although we currently do not have data for detrital POM. A change in dissolved inorganic nitrogen (DIN) baseline across estuarine salinity gradients (salinity $=0$ to 35) has been suggested by Fry (2002). Although there is no clear salinity gradient in the study area, it is possible that the $\delta^{15} \mathrm{~N}$ of DIN decreases offshore, resulting in the $\delta^{15} \mathrm{~N}$ of PP. Assuming that this hypothesis is true, the number of trophic levels increases from 3 to 4 in the transition from 
inshore to offshore areas, and the major contributor to the trophic link shifts from BM to PP.

Previous isotopic studies that showed systematic landward decreases in $\delta^{13} \mathrm{C}$ and/or $\delta^{15} \mathrm{~N}$ for estuarine consumers have suggested a change of food source from algae to terrestrial organic matter (Kikuchi \& Wada 1996, Riera \& Richard 1996, Doi et al. 2005, Kasai $\&$ Nakata 2005) or the consumption of PP with differing $\delta^{13} \mathrm{C}$ values, reflecting the source of dissolved inorganic carbon used for photosynthesis (Fry 1999, Piola et al. 2006). In our study area, however, such trends were not found, probably due to the more saline environment, where marine-influenced, nutritive primary producers such as PP and BM prevail. The present results are similar to those of Kang et al. (2003) who investigated isotopic compositions of macrobenthos collected from the southern coast of Korea, where extensive tidal flats develop. They concluded that deposit feeders inhabiting the tidal flat and subtidal bay bottoms depend exclusively on BM, suspension feeders depend on a mixture of PP and BM, offshore consumers depend exclusively on $\mathrm{PP}$, and reed and riverine POM are not used in the diet. The subtidal consumers obtained from Korean bays, however, had more enriched $\delta^{13} \mathrm{C}$ values ( -17 to $-12 \%$ ) in comparison with those in Gokasho Bay (ca. -20 to $-15 \%$ ), suggesting the stronger dependence of the Korean consumers on BM. Topographic and hydrological conditions, such as the area of the tidal flats (25 ha at the lowest ebb tide in Gokasho Bay) and tidal amplitude (1.7 $\mathrm{m}$ in Gokasho Bay vs $4 \mathrm{~m}$ in the Korean bays) may influence the relative importance of PP and BM.

\section{Effects of fish-farm wastes on the macrobenthos}

The $\delta^{15} \mathrm{~N}$ values of several consumers inhabiting the inner part of Gokasho Bay increased progressively in the seaward direction. There are 2 components that lead to an increase in $\delta^{15} \mathrm{~N}$ for consumers, viz. seaweeds and fish feed. Sargassum beds are well developed on the rocky shores around the central part of the bay (Yokoyama \& Ishihi 2003). Seaweeds, which had the most enriched $\delta^{15} \mathrm{~N}$ values (mean $=8.1 \%$ ) among the primary producers, may contribute to the enrichment of the $\delta^{15} \mathrm{~N}$ for consumers. However, as noted earlier, seaweeds cannot be a major food source for the majority of consumers. The other component is waste discharged from the fish farm located in the central part of the bay. Yokoyama et al. (2006) reported that aquaculture-derived organic matter (AOM) spread over $300 \mathrm{~m}$ from fish cages in the study area. AOM is mainly composed of waste feed, which has enriched $\delta^{15} \mathrm{~N}$ values (mean $=9.7 \%$ ). Fish meal and raw fish, the main constituents of dry and moist feed pellets, contain high amounts of protein which is digestible by benthic animals. Fish farming also discharges a large amount of dissolved organic matter and inorganic nitrogen in the form of liquid leaching from the feed as it unfreezes, and urea excreted from cultured fish (Kadowaki 1989, Hall et al. 1992). Such dissolved nutrients can be readily taken up by primary producers, and then incorporated by primary consumers. Vizzini \& Mazzola (2004) found that wastes discharged from a land-based fish farm affected the $\delta^{15} \mathrm{~N}$ values of the nearshore biota, and explained the mechanism of $\delta^{15} \mathrm{~N}$ level elevation. Nitrogen excreted in the form of urea is hydrolyzed to ammonia, a part of which is lost through volatilization, thereby enriching the ${ }^{15} \mathrm{~N}$ fraction of the remaining ammonia, thus forming ${ }^{15} \mathrm{~N}$-enriched nitrates; these nitrogenous nutrients are subsequently taken up by primary producers and enter the food web. Vizzini \& Mazzola (2004) also found that the effects of the effluent from a small-scale fish farm (fish produc-

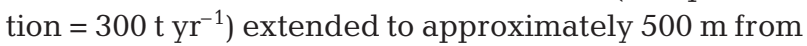
the outfall. Taking into account the large-scale fish farm (1248 $\left.\mathrm{t} \mathrm{yr}^{-1}\right)$ in our study area and the aquaculture effluents discharged directly into the surrounding water body, it is probable that impacts of aquaculturederived dissolved nitrogen extend $>1 \mathrm{~km}$ from the fish cages. Evidence for the incorporation of AOM by consumers is also supported by the finding that several dominant species at the farm site had enriched $\delta^{15} \mathrm{~N}$ values relative to specimens collected from outside the farm area (Fig. 8b). The ${ }^{15} \mathrm{~N}$-enrichment may be due to the direct uptake of ${ }^{15} \mathrm{~N}$-enriched components in fish feed such as fish meal and minced raw fish.

There were significant differences in $\delta^{13} \mathrm{C}$ between consumers collected from the fish-farm stations and those from the other stations. A comparison of the $\delta^{13} \mathrm{C}$ values for the same species also revealed that the majority of the samples collected from the fish farm had depleted $\delta^{13} \mathrm{C}$ values. These findings suggest that the consumers assimilate ${ }^{13} \mathrm{C}$-depleted fish feces preferentially, and these contain large quantities of terrestrial plant materials, such as wheat flour, defatted soybean meal and defatted rice bran meal (Yokoyama et al. 2006). On the other hand, there was no clear difference in the $\delta^{15} \mathrm{~N}$ pattern for macrofauna between the inside and outside the fish farm. The reason for this remains an enigma; however terrestrial plants have depleted $\delta^{15} \mathrm{~N}$ values, which may decrease the $\delta^{15} \mathrm{~N}$ values in consumers, thus compensating for the increased $\delta^{15} \mathrm{~N}$ that resulted from the incorporation of the ${ }^{15} \mathrm{~N}$ enriched constituents in the fish feed.

In conclusion, the stable isotope data for nearshore coastal consumers collected from a land-sea transect showed that the isotopic compositions changed progressively seaward, suggesting a shift in the food source from benthic microalgae to coastal phytoplank- 
ton and the incorporation of fish-farm wastes by the macrobenthos inhabiting and surrounding the fish farm. The present study suggests the importance of locally produced microalgae and anthropogenic inputs as food sources. However, the contribution of fish farm wastes to the coastal consumers cannot be quantitatively evaluated, because wastes are composed of a mixture of different sources whose isotopic values overlap with those of natural sources. It may be that seaweeds play a lesser but significant role as a food source, however, for the same reason we could not calculate their contribution rate. When we determine diets of coastal consumers which have multiple potential food sources with overlapping isotope values, problems still exist and additional, independent information may be necessary to validate conclusions (Lee 2005); however, surveys along land-sea transects provide valid information on the relative importance of the different food sources.

Acknowledgements. We thank S. Yamamoto for his help during the sample collection. This research was conducted under the project study entitled 'Integrated Study on the Development of Natural Cyclical Functions through Forest, Agricultural and Aquatic Ecosystems', which is funded by the Agriculture, Forestry and Fisheries Research Council, Japan.

\section{LITERATURE CITED}

Abo K (2000) Fluctuation of hypoxic water masses in a fish farming ground of semi-enclosed estuary facing the ocean. Bull Natl Res Inst Aquacult 29:141-216 (in Japanese with English abstract)

Abo K, Toda S, Takayanagi K, Sakami T and 5 others (2000) Records of oceanographic observation in Gokasho Bay, Mie Prefecture (June 1989-March 1999). National Research Institute of Aquaculture, Mie (in Japanese)

Cividanes S, Incera M, López J (2002) Temporal variability in the biochemical composition of sedimentary organic matter in an intertidal flat of the Galician coast (NW Spain). Oceanol Acta 25:1-12

Conway NM, Howes BL, McDowell Capuzzo JE, Turner RD, Cavanaugh CM (1992) Characterization and site description of Solemya borealis (Bivalvia; Solemyidae), another bivalve-bacteria symbiosis. Mar Biol 112:601-613

DeNiro MJ, Epstein S (1978) Influence of diet on the distribution of carbon isotopes in animals. Geochim Cosmochim Acta 42:495-506

DeNiro MJ, Epstein S (1981) Influence of diet on the distribution of nitrogen isotopes in animals. Geochim Cosmochim Acta 45:341-351

Doi H, Matsumasa M, Toya T, Satoh N, Mizota C, Maki Y, Kikuchi E (2005) Spatial shifts in food sources for macrozoobenthos in an estuarine ecosystem: carbon and nitrogen stable isotope analyses. Estuar Coast Shelf Sci 64:316-322

Fry B (1999) Using stable isotopes to monitor watershed influences on aquatic trophodynamics. Can J Fish Aquat Sci 56: 2167-2171

Fry B (2002) Conservative mixing of stable isotopes across estuarine salinity gradients: a conceptual framework for monitoring watershed influences on downstream fisheries production. Estuaries 25:264-271

Hall POJ, Holby O, Kollberg S, Samuelsson MO (1992) Chemical fluxes and mass balances in a marine fish cage farm. IV. Nitrogen. Mar Ecol Prog Ser 89:81-91

Herman PMJ, Middelburg JJ, Widdows J, Lucas CH, Heip CHR (2000) Stable isotopes as trophic tracers: combining field sampling and manipulative labelling of food resources for macrobenthos. Mar Ecol Prog Ser 204:79-92

Horikoshi M (1990) Macrobenthic communities in Japanese coastal waters. In: Coastal Oceanography Research Committee, The Oceanographic Society of Japan (ed) Coastal oceanography of Japanese islands, Suppl Vol. Tokai University Press, Tokyo, p 283-311 (in Japanese)

Imhoff JF, Sahling H, Süling J, Kath T (2003) 16S rDNAbased phylogeny of sulphur-oxidising bacterial endosymbionts in marine bivalves from cold-seep habitats. Mar Ecol Prog Ser 249:39-51

Iwasaki S, Yamamoto K, Jinushi A, Takahashi M, Hatanaka K (1997) Study of water quality control in enclosed bays: behavior of eutrophicating substances in major river which flow into the Gokasyo Bay. Rep Environ Sci Inst Mie Pref 17: 55-60 (in Japanese with English abstract)

Kadowaki S (1989) Oxygen consumption of remaining feed and feces in pen culture of yellowtail Seriola quinqueradiata and red sea bream Pagrus major. Suisanzoshoku 37: $27-33$

Kanaya G, Nobata E, Toya T, Kikuchi E (2005) Effects of different feeding habits of three bivalve species on sediment characteristics and benthic diatom abundance. Mar Ecol Prog Ser 299:67-78

Kasai A, Nakata A (2005) Utilization of terrestrial organic matter by the bivalve Corbicula japonica estimated from stable isotope analysis. Fish Sci 71:151-158

Kasai A, Horie H, Sakamoto W (2004) Selection of food sources by Ruditapes philippinarum and Mactra veneriformis (Bivalva: Mollusca) determined from stable isotope analysis. Fish Sci 70:11-20

Kang CK, Kim JB, Lee KS, Kim JB, Lee PY, Hong JS (2003) Trophic importance of benthic microalgae to macrozoobenthos in coastal bay systems in Korea: dual stable C and N isotope analyses. Mar Ecol Prog Ser 259:79-92

Kikuchi E, Wada E (1996) Carbon and nitrogen stable isotope ratios of deposit-feeding polychaetes in the Nanakita River Estuary, Japan. Hydrobiologia 321:69-75

Lee SY (2005) Exchange of organic matter and nutrients between mangroves and estuaries: myths, methodological issues and missing links. Int $\mathrm{J}$ Ecol Environ Sci 31:163-176

McCutchan JH Jr, Lewis WM Jr, Kendall C, McGrath CC (2003) Variation in trophic shift for stable isotope ratios of carbon, nitrogen, and sulfur. Oikos 102:378-390

Minagawa M, Wada E (1984) Stepwise enrichment of ${ }^{15} \mathrm{~N}$ along food chains: further evidence and the relation between $\delta^{15} \mathrm{~N}$ and animal age. Geochim Cosmochim Acta 48:1135-1140

Nomura K (1940) On the methods of comparison of insect-faunae, with special reference to the correlation method. Sci Bull Fac Agric Kyushu Univ 9:235-262 (in Japanese with English abstract)

Phillips DL, Gregg JW (2003) Source partitioning using stable isotopes: coping with too many sources. Oecologia 136: 261-269

Piola RF, Moore SK, Suthers IM (2006) Carbon and nitrogen stable isotope analysis of three types of oyster tissue in an impacted estuary. Estuar Coast Shelf Sci 66:255-266

Riera P, Richard P (1996) Isotopic determination of food sources of Crassostrea gigas along a trophic gradient in the estuar- 
ine bay of Marennes-Oléron. Estuar Coast Shelf Sci 42: $347-360$

Sasaki R, Oshino A (2004) Environmental conditions relevant to aggregative distribution of macrobenthos below coho salmon culture cage. Bull Fish Res Agency, Suppl 1:19-31

Schimmelmann A, DeNiro MJ (1986) Stable isotopic studies on chitin. II. The ${ }^{13} \mathrm{C} /{ }^{12} \mathrm{C}$ and ${ }^{15} \mathrm{~N} /{ }^{14} \mathrm{~N}$ ratios in arthropod chitin. Contrib Mar Sci 29:113-130

Simpson GG (1960) Notes on the measurement of faunal resemblance. Am J Sci 258A:300-311

Tsutsumi H (1995) Impact of fish net pen culture on the benthic environment of a cove in south Japan. Estuaries 18: 108-115

Vizzini S, Mazzola A (2004) Stable isotope evidence for the environmental impact of a land-based fish farm in the western Mediterranean. Mar Pollut Bull 49:61-70

Yokoyama H (2002) Impact of fish and pearl farming on the benthic environments in Gokasho Bay: evaluation from seasonal fluctuations of the macrobenthos. Fish Sci 68:258-268

Yokoyama H, Ishihi Y (2003) Feeding of the bivalve Theora lubrica on benthic microalgae: isotopic evidence. Mar

Editorial responsibility: Otto Kinne (Editor-in-Chief), Oldendorf/Luhe, Germany
Ecol Prog Ser 255:303-309

Yokoyama H, Ishihi Y (2006) Variation in $\delta^{13} \mathrm{C}$ and $\delta^{15} \mathrm{~N}$ among different tissues of three estuarine bivalves: implications for dietary reconstructions. Plankton Benthos Res 1:178-182

Yokoyama H, Higano J, Adachi K, Ishihi Y, Yamada Y, Pichitkul P (2002) Evaluation of shrimp polyculture system in Thailand based on stable carbon and nitrogen isotope ratios. Fish Sci 68:745-750

Yokoyama H, Tamaki A, Harada K, Shimoda K, Koyama K, Ishihi Y (2005a) Variability of diet-tissue isotopic fractionation in estuarine macrobenthos. Mar Ecol Prog Ser 296: $115-128$

Yokoyama H, Tamaki A, Koyama K, Ishihi Y, Shimoda K, Harada K (2005b) Isotopic evidence for phytoplankton as a major food source for macrobenthos on an intertidal sandflat in Ariake Sound, Japan. Mar Ecol Prog Ser 304: 101-116

Yokoyama H, Abo K, Ishihi Y (2006) Quantifying aquaculturederived organic matter in the sediment in and around a coastal fish farm using stable carbon and nitrogen isotope ratios. Aquaculture 254: 411-425

Submitted: September 29, 2006; Accepted: April 11, 2007 Proofs received from author(s): September 6, 2007 